Original Article

\title{
GAS CHROMATOGRAPHY STUDY OF N-HEXANE AND CHLOROFORM FRACTIONS OF ETHANOL EXTRACT OF MELASTOMA MALABATHRICUM L. LEAVES: AN IN VITRO STUDY OF ANTIOXIDANT AND SPF VALUES
}

\author{
P. APRIDAMAYANTI ${ }^{*}$ iD , L. PRATIWI ${ }^{2}$ iD R. SARI $^{3}$ \\ 1,2,3Pharmacy Department, Faculty of Medicine, Tanjungpura University, Pontianak 78124, Indonesia \\ Email: apridamayanti.pratiwi@gmail.com
}

Received: 08 Dec 2021, Revised and Accepted: 25 Jan 2022

\section{ABSTRACT}

Objective: This research aimed to qualitatively determine the chemical compound constituents, antioxidant capacity, and sun protection factor (SPF) value of extract of the leaves of Melastoma malabathricum L. using GC-MS.

Methods: The detected compounds were identified by processing the raw GC-MS data using ChemStation software and comparing results with the NIST mass spectral database. Antioxidant capacity was measured using 1,2-diphenyl-2-picrylhydrazyl (DPPH) radical-scavenging and ferricreducing antioxidant power (FRAP) assays. The SPF contained in the n-hexane and chloroform fractions separated from the ethanol extract of the leaves of Melastoma malabathricum L was identified.

Results: The GC-MS test results revealed that 21 and 29 peaks of separation occurred in the n-hexane and chloroform fractions. The highest peak values are hexadecanoic acid methyl ester (a fatty acid group also known as palmitic acid) (100\%) in the n-hexane and chloroform fractions. The highest chemical content in n-hexane and chloroform fractions was obtained at $20 \mathrm{~min}$. The thin-layer chromatography (TLC) results indicated that the n-hexane and chloroform fractions contained steroid and terpenoid compounds. The antioxidant capacity test using DPPH showed that the nhexane and chloroform fractions of ethanol extract of the leaves of Melastoma malabathricum L had IC 50 values of $49.2 \pm 7.9 \mathrm{~g} / \mathrm{ml}$ and $11.3 \pm 3.65$ $\mathrm{g} / \mathrm{ml}$, respectively. Using FRAP, the $\mathrm{IC}_{50}$ values of the $\mathrm{n}$-hexane and chloroform fractions were identified as $365.2 \pm 133.6 \mathrm{~g} / \mathrm{ml}$ and $80.8 \pm 8.9 \mathrm{~g} / \mathrm{ml}$, respectively, categorizing them as strong and weak antioxidants. SPF testing produced SPF values for the n-hexane and chloroform fractions of ethanol extract of Melastoma malabathricum L leaves of $11.7 \pm 0.1$ and $21 \pm 0.4$, respectively.

Conclusion: The study results show that the antioxidant activity and the SPF values of the chloroform fraction are greater than those of the nhexane fraction. In conclusion, the n-hexane and chloroform fractions are found to have antioxidant properties in the weak and solid categories and the ability to protect against sunlight in the vulnerable category.

Keywords: GC-MS, n-hexane fraction, Chloroform fraction, Antioxidant, SPF value

(C) 2022 The Authors. Published by Innovare Academic Sciences Pvt Ltd. This is an open access article under the CC BY license (https://creativecommons.org/licenses/by/4.0/) DOI: https://dx.doi.org/10.22159/ijpps.2022v14i3.43801. Journal homepage: https://innovareacademics.in/journals/index.php/ijpps.

\section{INTRODUCTION}

Sunlight affects human skin via UV radiation, causing sunburn, skin cancer, skin pigmentation, and premature aging. It is, therefore, necessary to develop sunscreen formulations to protect against sunburn, skin cancer, and early skin aging [1]. UVR rays are divided into three main groups: UVA with a wavelength range of 320 to $400 \mathrm{~nm}$; UVB: with the wavelength range of 280 to $320 \mathrm{~nm}$; and UVC with the wavelength range of 100 to $280 \mathrm{~nm}$ [2]. Ultraviolet C emission (UVC) is the most dangerous UVC light that can cause mutagenicity and erythematous. UVB affects the stratum corneum of the skin and can trigger the release of inflammatory mediators such as histamine, serotonin, and prostaglandins that causes capillary dilation and the development of erythema and edema $[3,4]$. UVA radiation can stimulate pigment production more than other UV radiation. UVA radiation penetrates the deeper layers of the dermis and impairs normal cell function, affecting blood vessels and collagen fibers. UVA light indirectly affects cellular DNA by generating reactive oxygen species [2].

Melastoma malabathricum L. found in Indonesia has several local names, including kluruk (Javanese), haredong (Sundanese), sak (Dayak), and kemanden (Maduran) [5]. Melastoma malabathricum L. is used as a herbal medicine in several Asian countries, including India, Malaysia, Indonesia, and Singapore. It has been known to have various medicinal benefits based on the traditional practices and beliefs of different communities and tribes [6]. Plants have evolved self-protection mechanisms to avoid damage because, in plants, exposure to sunlight is required for photosynthesis. Bioactive compounds such as phenol have antioxidant properties in plants [7, 8]. As a result, phytochemical analysis of plants has become an increasingly important method in plant medicine and drug research [9]. The study conducted by Amini et al., 2019 found a positive relationship between DPPH radical protection activity (IC50), total phenolic content, and total flavonoids, with SPF values with R2 values of $-0.9603,0.8999$, and 0.8476 , respectively. The results of Amini et al., 2019 research show that purified extract of Elaeagnus angustifolia has high phenol and flavonoid content (with an IC50 of $4.5 \mu \mathrm{g} / \mathrm{ml}$ ) and has the highest SPF value of $29.73 \pm 0.31$ [10]

Research into the existence of compounds with sun protection properties in Melastoma malabathricum L has not yet been carried out, with the focus of previous studies being on antioxidant activity in extracts and parts of the plant. This study examined the chemical content of the separated compounds in ethanolic extract of the plant Melastoma malabathricum L. using different solvent polarities, namely n-hexane and chloroform. This Melastoma malabathricum L. content analysis study was carried out using the thin-layer chromatography (TLC) technique followed by GC-MS. In vitro examination of antioxidant activity was conducted using DPPH and FRAP to confirm antioxidant activity in the plant's constituent compounds. In vitro testing of the ability to protect against UV rays in terms of SPF can be a reference source in tracing sources of cosmetic raw materials derived from medicinal plants.

\section{MATERIALS AND METHODS}

Material

Oven (Modena), camera (Canon), rotary evaporator (Butchi), ultrasonicator (Branson 1510), spectrophotometer UV/Vis 
(Shimadzu), Agilent JandW GC column type DB-5MS (30 m x 0.25 $\mathrm{mm}$ ), Agilent Gas Chromatography GC: 7890A (G3440A), Thin Layer Chromatography silica gel $60 \mathrm{~F}_{254}$ (Merck), Whatman (Merck).

\section{Chemicals}

Ethanol (Merck), ethanol (Brataco), n-hexane (Brataco), Ethyl acetate (Merck), Formic acid (Merck), Chloroform (Merck), $\mathrm{HCl}$ (Merck), $\mathrm{AlCl}_{3}$ (Merck), $\mathrm{FeCl}_{3}$ (Merck), metal $\mathrm{Mg}, \mathrm{H}_{2} \mathrm{SO}_{4}$ (Merck), TPTZ (Merck) reagent, Citric acid (Merck), Ascorbic acid (Merck), 1,1-Diphenyl-2picrylhydrazyl radical (DPPH) (Merck), and vanillin-sulfuric acid 10\%.

\section{Collection and authentication of plant samples}

Melastoma malabathricum L. samples were collected in the Punggur Besar village, Kubu Raya Sub-district, Pontianak, West Borneo, Indonesia. Authentication was by the Biology Faculty of Tanjungpura University (26 Sep 2016).

\section{Extraction}

The dried powder of Melastoma malabathricum L was extracted with $78 \%$ ethanol by maceration method and rotary evaporator apparatus to reduce solvent and crude extract. The crude extract was then separated using a funnel with solvents of different polarities: $n$-hexane and chloroform [11]. Thus, we obtained $\mathrm{n}$-hexane and chloroform fractions. The dried fraction was stored at room temperature.

Preliminary phytochemical screening and thin-layer chromatography

Preliminary phytochemical testing was carried out to investigate the presence of secondary metabolites. According to standard practice, phenol, flavonoid, alkaloid, steroid, anthraquinone, tannin, and saponin tests were carried out [12].

Confirmation testing of secondary metabolic content of n-hexane and chloroform fractions with TLC identification of stationary phase was carried out via silica gel $60 \mathrm{~F}_{254}$. The mobile phase is $\mathrm{n}$-hexane: ethyl acetate: formic acid at $10 \mathrm{ml}: 10 \mathrm{ml}: 8$ drops. Spot viewers used in this study were $\mathrm{AlCl}_{3}, \mathrm{FeCl}_{3}$, and $\mathrm{H}_{2} \mathrm{SO}_{4} 10 \%$, and vanillin-sulfuric acid 10\% [13].

\section{Preparation of GC-MS analysis}

The preparation of GC-MS analysis in this study followed Prakash and Meena's method. Five milligrams samples of fractions were obtained by separating the ethanol extract of Melastoma malabathricum L, namely the n-hexane fraction and the chloroform fraction, which were then dissolved using $3 \mathrm{ml}$ of chloroform. The solution was sonicated for 1 minute, after which chloroform was added to the $5 \mathrm{ml}$ mark on the volumetric flask. GC-MS analysis was performed using an Agilent JandW GC column type DB-5MS (30 m x $0.25 \mathrm{~mm}$ ). A total of $1 \mathrm{~L}$ of sample solution was injected into Agilent Gas Chromatography GC: 7890A (G3440A) for $40 \mathrm{~min}$, with the injection port temperature at $230^{\circ} \mathrm{C}$. Helium was used as the carrier gas. MS was operated in the electron impact mode with ionization energy of $70 \mathrm{eV}$. Full scan mass spectra were acquired from 30 to $380 \mathrm{~m} / \mathrm{z}$. Detected compounds were identified by processing the raw GC/MS data with ChemStation software and comparing results with the mass spectral database [14].

\section{Antioxidant activities with DPPH and FRAP method}

Antioxidant activity was tested using a 1,1-Diphenyl-2-picrylhydrazyl radical (DPPH) assay to identify the sample's free-radical-scavenging activity. The technique used in this study is following Brand-Williams et al., 1995 and Kikuzaki et al., 2002 [15, 16]. $1 \mathrm{ml}$ of each sample with various concentrations (0.5-250 ppm) was added to $3 \mathrm{ml}$ of DPPH 1 $\mathrm{mmol}$ and $1 \mathrm{ml}$ methanol. This was then incubated in the dark for 15 min at room temperature, and absorbance was measured at $515.5 \mathrm{~nm}$. Experiments were carried out in triplicate and ascorbic acid as comparison compounds in this study.

Antioxidant activity testing with FRAP was performed according to Syamsu et al., 2017. $30 \mu \mathrm{l}$ of each sample with various concentrations of $1 \mu \mathrm{g} / \mathrm{ml}$ to $650 \mu \mathrm{g} / \mathrm{ml}$ were added to $30 \mu \mathrm{FeCl}$ solution ( $3 \mathrm{mmol}$ in $5 \mathrm{mmol}$ citric acid) and $240 \mu \mathrm{l}$ TPTZ reagent (1 mmol in $0.05 \mathrm{M} \mathrm{HCL}$ ) in 96 microplate wells. Incubation was for 20 min at room temperature, and absorbance was measured at $615 \mathrm{~nm}$ [17]. The results in this study are presented in triplicate using vitamin C (ascorbic acid) as a comparison compound.

\section{Identification in vitro of SPF}

The n-hexane and chloroform fractions that form the samples in this study were dissolved in ethanol at a $250 \mu \mathrm{g} / \mathrm{ml}$ concentration and scanned across the 290 to $320 \mathrm{~nm}$ range at five $\mathrm{nm}$ intervals. Screening of sun protection activity was measured by determination in vitro of SPF, based on the equation proposed by Mansur., 1986 [18].

$$
\mathrm{SPF}=\mathrm{CF} \times \sum_{290}^{320} \operatorname{EE}(\lambda) \mathrm{xI}(\lambda) \mathrm{x} \operatorname{Abs}(\lambda)
$$

Note: $C F$ is the correction factor; $E E$ is the erythema effect in the spectrum (nm); $I$ is light intensity (nm), and $A b s$ is the absorbance sample. The absorbance sample was measured three times and used for SPF calculation.

\section{Statistical analysis}

Data are presented as means \pm standard deviation. Statistical analysis was performed using SPSS software to analyze statistical significance, with a value of $\mathrm{p}<0.05$ considered significant.

\section{RESULTS}

\section{The percentage yield of extract and fraction}

Details of the n-hexane and chloroform fractions of ethanol extract of Melastoma malabathricum L. obtained in this study are presented in table 1.

Table 1: Composition of ethanol 78\% extract yield of Melastoma malabathricum $L$. leaves

\begin{tabular}{ll}
\hline Sample & Percentage yield (\%w/w) \\
\hline Hexane fraction & 3.16 \\
Chloroform fraction & 9.29 \\
\hline
\end{tabular}

\section{Preliminary phytochemical screening and thin-layer chromatography (TLC)}

Initial phytochemical screening tests were carried out to determine the content of secondary metabolites. The results are shown in table 2. Confirmation tests of secondary metabolites of n-hexane and chloroform fractions of ethanol extract of Melastoma malabathricum L. were performed using TLC, as presented in fig. 1.

Table 2: Screening of secondary metabolite content in extracts and fractions from Melastoma malabathricum L. leaves

\begin{tabular}{lll}
\hline Secondary metabolite & N-hexane fraction & Chloroform fraction \\
\hline Phenols & - & + \\
Flavonoids & -+ & + \\
Alkaloids & +++ & + \\
Terpenoids & - & - \\
Steroids & +++ & ++ \\
Anthraquinone & - & - \\
Tannins & - & - \\
Saponins & - & - \\
\hline
\end{tabular}

Key: = absent; += present in small quantity; ++= present in moderate quantity; +++= present in large quantity 
a. Spot sight with sulfuric acid $10 \%$

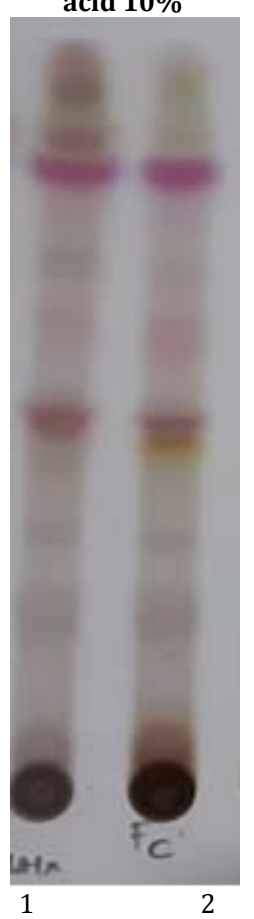

b. Spot sight with $\mathrm{AlCl}_{3}$

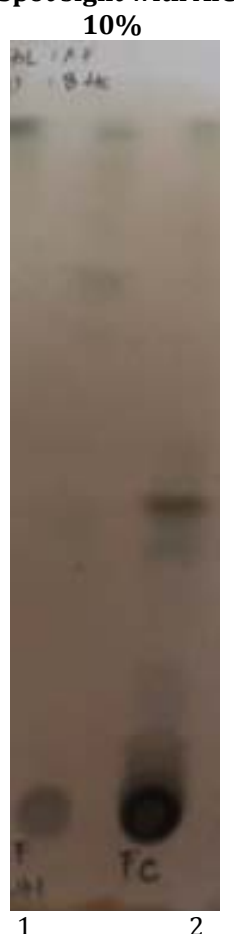

c. Spot sight with $\mathrm{FeCl}_{3}$

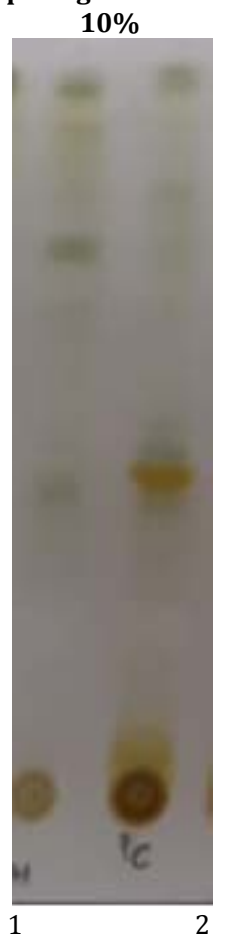

\section{d. Spot sight with vanillin-sulfuric acid $10 \%$ after heating at $95^{\circ} \mathrm{C}$ for $5 \mathrm{~min}$}

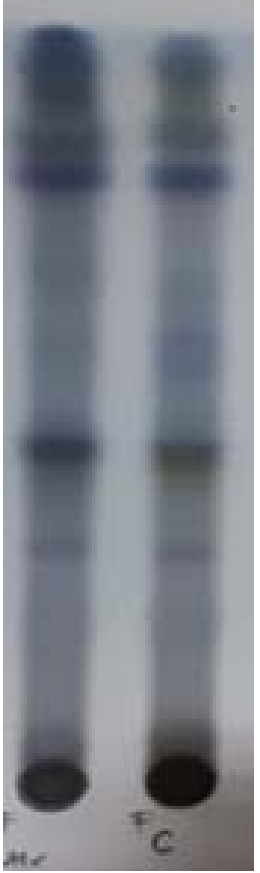

Fig. 1: TLC separation sample of mobile phase n-hexane: ethyl acetate: formic acid (10 ml: $10 \mathrm{ml}: 8 \mathrm{drops})$ and stationary phase silica gel $F_{254}$. Sample volume $=10 \mu \mathrm{l}$, Key: 1 . N-hexane fraction; 2 . Chloroform fraction

\section{GC-MS analysis of n-hexane and chloroform fractions}

The chemical compositions of the n-hexane and chloroform fractions of ethanol extract of Melastoma malabathricum L. were determined by GC-MS and are presented in tables 3 and 4.

The antioxidant activity identified using DPPH and FRAP methods

Investigating antioxidant activity in n-hexane and chloroform fractions of ethanol extract of Melastoma malabathricum L. leaves were carried out using the DPPH and FRAP methods. The DPPH method identifies the ability of a sample to donate hydrogen and act as a radical scavenger. Meanwhile, the FRAP method converts hydrogen peroxide into hydroxyl radicals as an iron-reducing antioxidant. Investigation results for the antioxidant properties of Melastoma malabathricum L. can be seen in table 5 .

\section{SPF value of Melastoma malabathricum L. fractions}

Screening of sun protection activity was measured by determining in vitro SPF using the Mansur equation [18]. The result is presented in table 6.

Table 3: GC-MS results for the n-hexane fraction of Melastoma malabathricum L

\begin{tabular}{|c|c|c|c|c|c|}
\hline No & $\begin{array}{l}\text { Retention } \\
\text { time in min }\end{array}$ & Name of compound & $\begin{array}{l}\text { Molecule } \\
\text { formula }\end{array}$ & $\begin{array}{l}\text { Percent } \\
\text { peak value }\end{array}$ & $\begin{array}{l}\text { Nature of } \\
\text { compound }\end{array}$ \\
\hline 1 & 15.17 & 2(4H)-Benzofuranone, 5,6,7,7a-tetrahydro-4,4,7a-trimethyl & $\mathrm{C}_{11} \mathrm{H}_{16} \mathrm{O}$ & 2.58 & Monoterpene \\
\hline 2 & 17.26 & Tetradecanoic acid, 12-methyl, methyl ester & $\mathrm{C}_{16} \mathrm{H}_{32} \mathrm{O}_{2}$ & 1.07 & Fatty acid \\
\hline 3 & 18.56 & Tetradecanoic acid, 12-ethyl, methyl ester & $\mathrm{C}_{16} \mathrm{H}_{32} \mathrm{O}_{2}$ & 1.16 & Fatty acid \\
\hline 4 & 18.84 & 2-Pentadecanone, 6,10,14-trimethyl & $\mathrm{C}_{18} \mathrm{H}_{36} \mathrm{O}$ & 11.75 & Sesquiterpene \\
\hline 5 & 20.02 & 2-Piperidinone, N-[4-bromo-n-buthyl] & $\mathrm{C}_{9} \mathrm{H}_{16} \mathrm{NO}$ & 1.78 & - \\
\hline 6 & 20.09 & Hexadecanoic acid, methyl ester & $\mathrm{C}_{17} \mathrm{H}_{34} \mathrm{O}_{2}$ & 100 & Fatty acid ester \\
\hline 7 & 20.10 & 1-Hexadecen-3-ol, 3,5,11,15-tetramethyl & $\mathrm{C}_{20} \mathrm{H}_{40} \mathrm{O}$ & 2.06 & Diterpene \\
\hline 8 & 21.04 & Decosanoic acid, ethyl ester & $\mathrm{C}_{23} \mathrm{H}_{46} \mathrm{O}_{2}$ & 3.54 & Fatty acid \\
\hline 9 & 21.46 & Heptadecanoic acid, methyl ester & $\mathrm{C}_{18} \mathrm{H}_{36} \mathrm{O}_{2}$ & 1.21 & Fatty acid \\
\hline 10 & 22.29 & 9,12-Octadecadienoic acid, methyl ester (E, E) & $\mathrm{C}_{19} \mathrm{H}_{34} \mathrm{O}_{2}$ & 7.84 & Fatty Acid \\
\hline 11 & 22.37 & 9,12-Octadecadienoyl cloride, (Z,Z) & $\mathrm{C}_{18} \mathrm{H}_{31} \mathrm{ClO}$ & 13.08 & - \\
\hline 12 & 22.49 & Phytol & $\mathrm{C}_{20} \mathrm{H}_{40} \mathrm{O}$ & 1.18 & Diterpene \\
\hline 13 & 22.68 & Methyl stearate & $\mathrm{C}_{19} \mathrm{H}_{38} \mathrm{O}_{2}$ & 1.58 & - \\
\hline 14 & 23.63 & 2-Hexadecen-1-ol, 3,7,11,15-tetramethyl, acetate & $\mathrm{C}_{20} \mathrm{H}_{40} \mathrm{O}$ & 3.69 & Diterpene \\
\hline 15 & 24.79 & 2-Hexadecen-1-ol, 3,7,11,15, 17-pentamethyl, acetate & $\mathrm{C}_{20} \mathrm{H}_{40} \mathrm{O}$ & 2.22 & Diterpene \\
\hline 16 & 25.01 & 2-Hexadecen-1-ol, 3,7,11,15-tetramethyl, acetate & $\mathrm{C}_{20} \mathrm{H}_{40} \mathrm{O}$ & 2.16 & Diterpene \\
\hline 17 & 26.63 & 2-Hexadecen-1-ol, 3,7,11,15-tetramethyl, acetate & $\mathrm{C}_{20} \mathrm{H}_{40} \mathrm{O}$ & 5.07 & Diterpene \\
\hline 18 & 29.09 & 2-Hexadecen-1-ol, 3,7,11,15-tetramethyl, acetate & $\mathrm{C}_{20} \mathrm{H}_{40} \mathrm{O}$ & 5.34 & Diterpene \\
\hline 19 & 29.24 & 2-Hexadecen-1-ol, 3,7,11,15-tetramethyl, acetate & $\mathrm{C}_{20} \mathrm{H}_{40} \mathrm{O}$ & 6.91 & Diterpene \\
\hline 20 & 32.71 & 1,2-Bis(trimethylsilyl)benzene & $\mathrm{C}_{12} \mathrm{H}_{22} \mathrm{Si}_{2}$ & 9.73 & - \\
\hline 21 & 34.18 & 1,2-Bis(trimethylsilyl)benzene & $\mathrm{C}_{12} \mathrm{H}_{22} \mathrm{Si}_{2}$ & 7.58 & - \\
\hline
\end{tabular}


Table 4: GC-MS results for the chloroform fraction of Melastoma malabathricum L

\begin{tabular}{|c|c|c|c|c|c|}
\hline No & Retention time & Name of compound & $\begin{array}{l}\text { Molecule } \\
\text { formula }\end{array}$ & $\begin{array}{l}\text { Percent } \\
\text { peak value }\end{array}$ & $\begin{array}{l}\text { Nature of } \\
\text { compound }\end{array}$ \\
\hline 1 & 5.95 & Methane, dichloronitro & $\mathrm{CHC}_{12} \mathrm{NO}_{2}$ & 1.45 & Diena \\
\hline 2 & 7.79 & Butanedioic acid, dimethyl ester & $\mathrm{C}_{6} \mathrm{H}_{10} \mathrm{O}_{4}$ & 1.92 & Fatty acid \\
\hline 3 & 9.32 & Butanedioic acid, hydroxy-dimethyl ester & $\mathrm{C}_{6} \mathrm{H}_{10} \mathrm{O}_{5}$ & 4.77 & Fatty acid \\
\hline 4 & 10.39 & Butanedioic acid, hydroxy-dimethyl ester & $\mathrm{C}_{6} \mathrm{H}_{10} \mathrm{O}_{5}$ & 1.12 & Fatty acid \\
\hline 5 & 11.03 & Butanedioic acid, hydroxy-dimethyl ester & $\mathrm{C}_{6} \mathrm{H}_{10} \mathrm{O}_{5}$ & 1.49 & Fatty acid \\
\hline 6 & 12.39 & Oxalic acid, allyl hexadecyl ester & $\mathrm{C}_{21} \mathrm{H}_{38} \mathrm{O}_{4}$ & 1.24 & Fatty acid \\
\hline 7 & 15.17 & Nonanedioic acid, dimethyl ester & $\mathrm{C}_{11} \mathrm{H}_{20} \mathrm{O}_{4}$ & 7.41 & Fatty acid \\
\hline 8 & 15.51 & Phosphonofluoridic acid, (1-methyl ethyl)-cyclohexyl ester & $\mathrm{C}_{16} \mathrm{H}_{14} \mathrm{FO}_{2} \mathrm{P}$ & 1.36 & Fatty acid \\
\hline 9 & 16.05 & Phosphonofluoridic acid, (1-methyl ethyl)-cyclohexyl ester & $\mathrm{C}_{16} \mathrm{H}_{14} \mathrm{FO}_{2} \mathrm{P}$ & 1.27 & Fatty acid \\
\hline 10 & 16.42 & Phosphonofluoridic acid, (1-methyl ethyl)-cyclohexyl ester & $\mathrm{C}_{16} \mathrm{H}_{14} \mathrm{FO}_{2} \mathrm{P}$ & 1.81 & Fatty acid \\
\hline 11 & 16.94 & Phosphonofluoridic acid, (1,2-dimethyl ethyl)-cyclohexyl ester & $\mathrm{C}_{16} \mathrm{H}_{14} \mathrm{FO}_{2} \mathrm{P}$ & 2.28 & Fatty acid \\
\hline 12 & 17.20 & & & 1.05 & Fatty acid \\
\hline 13 & 18.00 & Phosphonofluoridic acid, (1-methyl ethyl)-cyclohexyl ester & $\mathrm{C}_{16} \mathrm{H}_{14} \mathrm{FO}_{2} \mathrm{P}$ & 3.99 & Fatty acid \\
\hline 14 & 18.17 & & & 1.51 & Fatty acid \\
\hline 15 & 18.56 & & & 2.80 & Fatty acid \\
\hline 16 & 20.02 & Phosphonofluoridic acid, (1-methyl ethyl)-cyclohexyl ester & $\mathrm{C}_{16} \mathrm{H}_{14} \mathrm{FO}_{2} \mathrm{P}$ & 1.85 & Fatty acid \\
\hline 17 & 20.10 & Hexadecanoic acid, methyl ester & $\mathrm{C}_{17} \mathrm{H}_{34} \mathrm{O}$ & 100 & Fatty acid \\
\hline 18 & 21.03 & Hexadecanoic acid, ethyl ester & $\mathrm{C}_{17} \mathrm{H}_{34} \mathrm{O}$ & 7.81 & Fatty acid \\
\hline 19 & 22.30 & E-11, Z-13-Octadecatriene & $\mathrm{C}_{18} \mathrm{H}_{32}$ & 5.45 & Fatty acid \\
\hline 20 & 22.37 & 9,12,15-Octadecatrienoic acid, methyl ester $(\mathrm{Z}, \mathrm{Z}, \mathrm{Z})$ & $\mathrm{C}_{19} \mathrm{H}_{32} \mathrm{O}$ & 15.57 & Fatty acid \\
\hline 21 & 22.67 & $9,12,15$-Octadecatrienoic acid, methyl ester $(\mathrm{Z}, \mathrm{Z}, \mathrm{Z})$ & $\mathrm{C}_{19} \mathrm{H}_{32} \mathrm{O}$ & 4.25 & Fatty acid \\
\hline 22 & 23.13 & $9,12,15$-Octadecatrienoic acid, methyl ester $(\mathrm{Z}, \mathrm{Z}, \mathrm{Z})$ & $\mathrm{C}_{19} \mathrm{H}_{32} \mathrm{O}$ & 1.20 & Fatty acid \\
\hline 23 & 28.31 & Cyclotrisiloxane, hexamethyl & $\mathrm{C}_{6} \mathrm{H}_{18} \mathrm{O}_{3} \mathrm{Si}_{3}$ & 1.53 & - \\
\hline 24 & 31.06 & Cyclotrisiloxane, hexamethyl & $\mathrm{C}_{6} \mathrm{H}_{18} \mathrm{O}_{3} \mathrm{Si}_{3}$ & 4.89 & - \\
\hline 25 & 31.62 & Cyclotrisiloxane, hexamethyl & $\mathrm{C}_{6} \mathrm{H}_{18} \mathrm{O}_{3} \mathrm{Si}_{3}$ & 1.57 & - \\
\hline 26 & 32.70 & 1,2 Bis(trimethylsilyl)benzene & $\mathrm{C}_{12} \mathrm{H}_{22} \mathrm{Si}_{22}$ & 82.84 & - \\
\hline 27 & 32.82 & 1,2 Bis(trimethylsilyl)benzene & $\mathrm{C}_{12} \mathrm{H}_{22} \mathrm{Si}_{22}$ & 1.19 & - \\
\hline 28 & 33.05 & Cyclotrisiloxane, hexamethyl & $\mathrm{C}_{6} \mathrm{H}_{18} \mathrm{O}_{3} \mathrm{Si}_{3}$ & 2.28 & - \\
\hline 29 & 34.18 & Cyclotrisiloxane, hexamethyl & $\mathrm{C}_{6} \mathrm{H}_{18} \mathrm{O}_{3} \mathrm{Si}_{3}$ & 15.61 & - \\
\hline
\end{tabular}

Table 5: Antioxidant activity of the n-hexane and chloroform fractions of Melastoma malabathricum L. and the standard compound

\begin{tabular}{lll}
\hline Sample & Antioxidant activity (IC $\mathbf{5 0}) \boldsymbol{\mu g} / \mathbf{m l}$ \\
\cline { 2 - 3 } & DPPH & FRAP \\
\hline N-hexane fraction & $49.2 \pm 7.9^{\mathrm{c}}$ & $365.2 \pm 133.6^{\mathrm{z}}$ \\
Chloroform fraction & $11.3 \pm 3.65^{\mathrm{b}}$ & $80.8 \pm 8.9^{\mathrm{y}}$ \\
Ascorbic acid & $1.9 \pm 0.2^{\mathrm{a}}$ & $4.13 \pm 0.86^{\mathrm{x}}$ \\
\hline
\end{tabular}

a,b,c Data different significantly $(\mathrm{p}<0.05)$ when compared with each other within the DPPH radical scavenging column, $\mathrm{x}, \mathrm{y}, \mathrm{z}$ Data different significantly $(\mathrm{p}<0.05)$ when compared with each other within the DPPH radical scavenging column

Table 6: SPF results for $n$-hexane and chloroform fractions of Melastoma malabathricum $\mathrm{L}$

\begin{tabular}{ll}
\hline Sample & SPF value (at $250 \mu \mathrm{g} / \mathrm{ml})$ \\
\hline N-hexane fraction & $11.7 \pm 0.1^{\mathrm{e}}$ \\
Chloroform fraction & $21.0 \pm 0.4^{\mathrm{f}}$ \\
\hline
\end{tabular}

e,fData different significantly $(\mathrm{p}<0.05)$ when compared with each other within the DPPH radical scavenging column

\section{DISCUSSION}

This study was performed to determine the qualitative content of the hexane and chloroform fractions in the ethanol extract of the leaves of Melastoma malabathricum L. with GC-MS analysis was used to identify and understand the critical properties of the active compounds. Active in medicinal plants; This study provides preliminary tests in the isolation of chemical compounds that have the potential to discover potential natural resources for sunscreen cosmetics. In vitro testing of antioxidant activity and the ability of compounds to protect the skin from UV rays was carried out to identify the potential of Melastoma malabathricum L as a source of natural cosmetics. A study conducted by Reddy et al., 2018 regarding new compounds as biological sources such as plants, minerals, and fish oil are known to have activity against solar radiation. They have antioxidant activity that can inactivate free radicals and show better protection than synthetic compounds because they are environmentally friendly. Research results that have been proven, such as the compound quercetin, Moringa oleifera, and Marcetia taxifolia have significant SPF activity when used as a sunscreen agent [19].

The first step in this research was to extract the Melastoma malabathricum L. leaf by maceration using $78 \%$ ethanol, obtaining a thick extract which was then separated using nhexane and chloroform liquid-liquid extraction. The yields of $n$ hexane and chloroform fractions of Melastoma malabathricum L. are as presented in table 1 . Phytochemical screening of the nhexane and chloroform fractions, as shown in table 2, reveals that n-hexane and chloroform fractions of Melastoma malabathricum L. contain alkaloids, phenols, flavonoids, and steroids. A confirmation test of the chemical content of the samples was carried out by TLC using a mobile phase of nhexane: ethyl acetate: formic acid (10 ml: $10 \mathrm{ml}: 8$ drops). Examination of terpenoids, steroids, and saponins using reagent spots by $10 \%$ vanillin and $10 \%$ sulfuric acid heated at $100{ }^{\circ} \mathrm{C}$ for 6 min produced blue-violet and red-violet spots [13].

The separation elution of the samples is shown in fig. 1 . Confirmation tests on the n-hexane and chloroform fractions confirmed their terpenoid and steroid content. In this study, qualitative examination of the secondary metabolite content of the n-hexane and the chloroform fractions of ethanol extract of Melastoma malabathricum L. identified alkaloids, steroids, terpenoids, phenols, and flavonoids. Research conducted in line with the previous study found that the n-hexane extract of Melastoma malabathricum L. is a terpenoid and a quinone $[14,20]$. 
A study of the chemical composition of the n-hexane and chloroform fractions was carried out using the GC-MS technique, with test results compared with the NIST mass spectra database. We diagnosed 21 chromatogram peaks inside the n-hexane fraction and 29 chromatogram peaks inside the chloroform fraction, with a separation time of five to $35 \mathrm{~min}$. The results of chromatogram separation using GC-MS can be seen in fig. 2 and 3 . Diterpenes and fatty acids dominate in the n-hexane and chloroform fractions, and the composition of peak values can be seen in tables 3 and 4 .

Qualitative Analysis Report

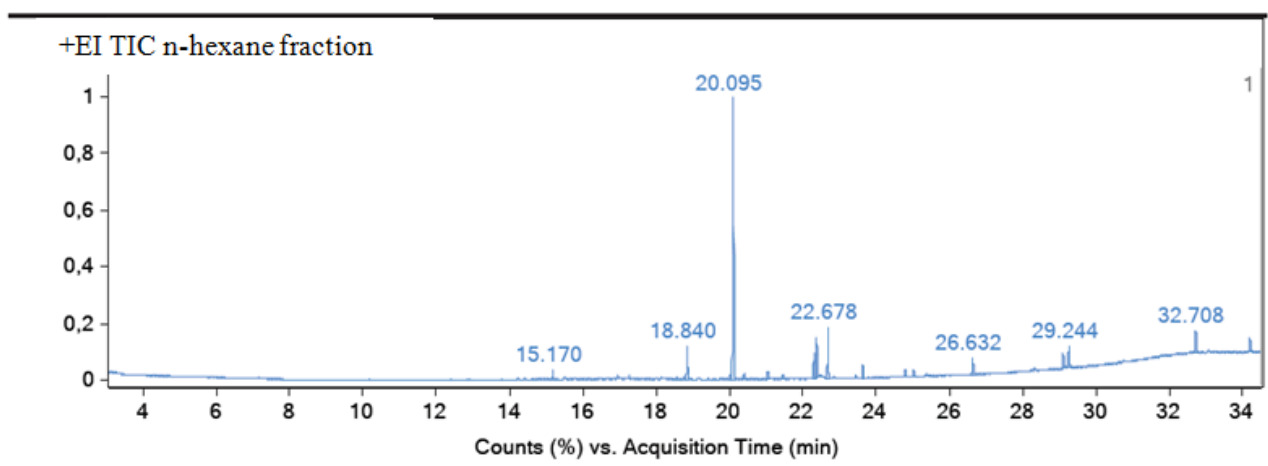

Fig. 2: GC-MS results for n-hexane fraction of Melastoma malabathricum $\mathrm{L}$

Qualitative Analysis Report

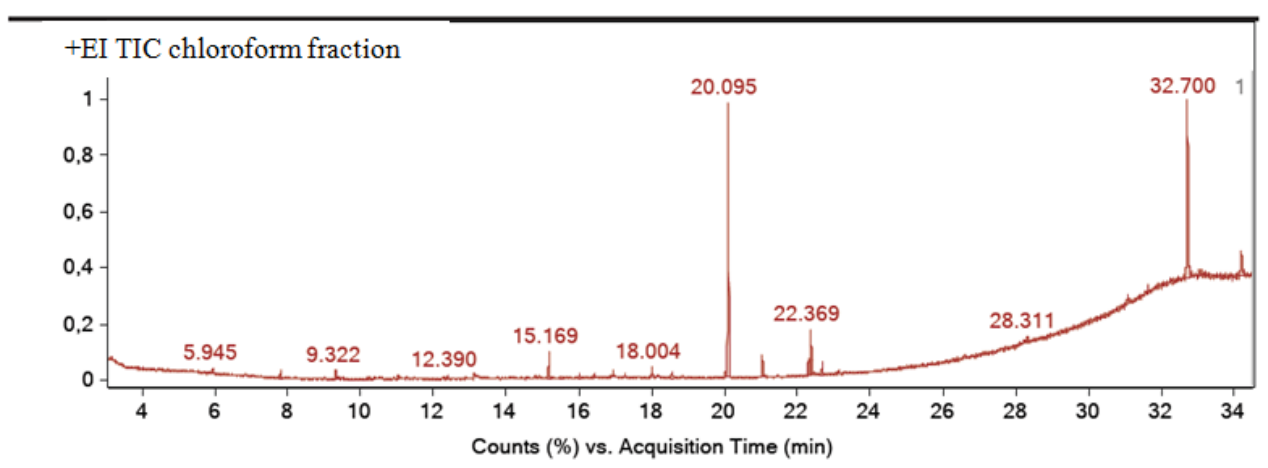

Fig. 3: GC-MS results for chloroform fraction of Melastoma malabathricum L

The GCMS results of the study showed that the compounds with antioxidant, anti-inflammatory, anticancer, and anticancer activities in the hexane fraction were methyl esters of tetradecanoic acid, methyl esters of tetradecanoic acid, hexadecanoic acid, phytol isomer, these compounds belong to the groups of fatty acids and terpenoids. GC-MS revealed compounds with antioxidant, antiinflammatory, and cancer prevention activities in the chloroform fraction: hexadecanoic acid-ethyl ester, cyclotrisiloxane-hexamethyl, and 1,2 Bis(trimethylsilyl)benzene [21]. These results are presented in tables 4 and 5 .

The most abundant chemical compound in both the n-hexane and chloroform fractions was 1-hexadecanoic acid methyl ester, obtained at $20 \mathrm{~min}$. The hexadecanoic acid methyl ester is a chemical compound belonging to the fatty acid methyl ester group (also known as palmitic acid) with antioxidant, antimicrobial, hypercholesterolemic, and hemolytic properties [21].

Diterpene compounds found in the n-hexane fraction comprise phytol isomer compounds known to have antimicrobial, anticancer, cancer preventive, anti-inflammatory, and antidiabetic biological properties [22, 23]. In in vitro testing, phytol is seen to reduce the production of free radicals by donating a hydrogen atom with an unpaired electron $\left(\mathrm{H}^{\cdot}\right)$, converting free radicals into unreactive species. The antioxidant activity of phytol can be related to its chemical structure as unsaturated alcohol with branched chains. Its antioxidant properties are ascribed to the hydroxyl group $(\mathrm{OH})$ present in the molecule [24]. A study by De Menezes Patrício Santos et al., 2013 showed that phytol could remove hydroxyl radicals
$(\mathrm{OH} \cdot)$, thus exhibiting antioxidant activity and inhibiting cell damage caused by these radicals [26]. In this study, hexadecanoic acid methyl ester, the chemical compound with the highest content in the chloroform fraction obtained at $20 \mathrm{~min}$, belongs to the fatty acid methyl ester group known as palmitic acid. It has antioxidant, antimicrobial, hypercholesterolemic, and hemolytic properties [21].

Antioxidant activity tests were carried out on the n-hexane and chloroform fractions using the DPPH and FRAP methods. The results of the antioxidant study obtained $\mathrm{IC}_{50}$ values for the $\mathrm{n}$-hexane fraction of the ethanol extract of Melastoma malabathricum $\mathrm{L}$ of 49.2 $\mu \mathrm{g} / \mathrm{ml}$ and $365.2 \mu \mathrm{g} / \mathrm{ml}$. The $\mathrm{IC}_{50}$ values were $11.3 \mu \mathrm{g} / \mathrm{ml}$ and 80.8 $\mathrm{g} / \mathrm{ml}$ in the chloroform fraction. The results are summarized in table 5 . These results show that the n-hexane fraction has both strong and weak antioxidant properties. In contrast, the chloroform fraction has only strong antioxidant activity, at $<100 \mu \mathrm{g} / \mathrm{ml}$ [26]. Vitamin C is a compound that is generally used as a comparison in antioxidant activity tests. The test results show that the order of antioxidant activity is vitamin $c>$ chloroform fraction $>$ n-hexane fraction with a confidence level of $p<0.05$. In line with the study of Jacob and John, 2020 plant Hypoesters phyllostachya extracted with the n-hexane solvent had the worst scavenging activity at a concentration of $500 \mu \mathrm{g} / \mathrm{ml}-2500 \mu \mathrm{g} / \mathrm{ml}$ compared with chloroform and methanol extraction by DPPH method [25].

The difference in antioxidant activity between the DPPH and FRAP tests reflects the compound responsible for the sample's classification as a secondary antioxidant. The compound stabilizes hydroperoxides by inhibiting the decomposition of hydroperoxides 
into free radicals. The FRAP antioxidant test method is based on the ability of a compound to reduce $\mathrm{Fe}^{3+}$ to $\mathrm{Fe}^{2+}$ through $\mathrm{Fe}^{3+}$ triptidyltriazine ( $\mathrm{Fe}^{3+}$-TPTZ) compounds so that an indicative color is formed as a result of the complex formed between the sample compound and $\mathrm{Fe}^{2+-} \mathrm{TPTZ}$ measured at the maximum absorbance wavelength. The decrease in absorbance is proportional to the concentration of antioxidants in the sample [27]. The mechanism of the FRAP method is different from the DPPH test. The concept of testing using the DPPH method is that compounds with antioxidant activity can donate hydrogen atoms, causing a reduction in the purple color of DPPH; thus, results are proportional to the number of compound molecules that have antioxidant activity [28]. The compound responsible has a mechanism for scavenging free radicals by rapidly donating or receiving hydrogen radicals by breaking the chain of radical reactions [29].

The antioxidant activity test results showed that the chloroform fraction had better antioxidative activity than the n-hexane fraction, with a $\mathrm{p}<0.05 \%$ confidence level. The content of fatty acid compounds in the chloroform fraction was more significant than in the n-hexane fraction (Tables 3 and 4). In the n-hexane fraction, six compounds found are classified as fatty acids, while in the chloroform fraction, 17 compounds classified areas fatty acids and two as linoleic-ester acids of the polyunsaturated fatty acid (PUFA) group, namely nonanedioic acid dimethyl ester and E-11, Z-13Octadecatriene. It is known that fatty acids can act as antioxidants through oxidative stress protection pathways in cells [30].

A study conducted by Da Silva, 2005 found that antioxidant activity plays an essential role in UV protection [31]. Quercetin is a compound that has been tested and has the potential as a topical sunscreen factor able to protect against UVA and UVB rays in human beings [32]. This study tested the ability to protect against sunlight through the SPF test, a quantitative method for measuring the effectiveness of sun protection products. Protective effects must have the ability to absorb light at wavelengths in the range of 290 to $400 \mathrm{~nm}$. The evaluation used in this study is the in vitro measurement of SPF value, this being the initial stage in screening potential products. The SPF test results for the n-hexane and chloroform fractions are 11.7 and 21.0, respectively, as shown in table 6 . The results showed that the chloroform fraction had a higher SPF value than the $n$-hexane fraction with a $p<0.05$ confidence level. It is possible that the type of fatty acid compounds contained in the chloroform fraction can offer increased protection against sunlight. Previous studies show that fatty acids can protect the skin from UV rays through protective mechanisms against the effects of UV rays, such as erythema and epidermal lipid peroxidation, via photoprotective and anti-inflammatory properties [33-37]. In this study, it is identified that the chloroform fraction contains phytol compounds, and it is posited that there is the biological activity of phytols associated with sun protection. The antioxidant activity of phytols was investigated in a previous study, revealing a relationship among others between reducing the production of free radicals and the active compounds attributed to their structural features. Phytols are branched unsaturated chain alcohols, and their antioxidant properties may be related to the hydroxyl group $(\mathrm{OH})$ present in the molecule. Several previous studies have shown that oxidative stress has a vital role in the nociceptive signaling involved in pain in the neuropathy and inflammation resulting from adverse effects of sunlight on the skin. As a result, phytols may play a role in protecting the skin from the sun [26].

\section{CONCLUSION}

The GC-MS test results found the highest number of peak values for hexadecanoic acid methyl ester (100\%) in the n-hexane fraction and the fatty acid group known as palmitic acid in the chloroform fraction. The DPPH, antioxidant capacity test showed $\mathrm{IC}_{50}$ values of $49.2 \pm 7.9 \mu \mathrm{g} / \mathrm{ml}$ and $11.3 \pm 3.65 \mu \mathrm{g} / \mathrm{ml}$ for the n-hexane and the chloroform fractions, respectively. The FRAP antioxidant capacity tests indicated $\mathrm{IC}_{50}$ values of the $\mathrm{n}$-hexane and chloroform fractions in the strong and weak antioxidants category of $365.2 \pm 133.6 \mu \mathrm{g} / \mathrm{ml}$ and $80.8 \pm 8.9 \mu \mathrm{g} / \mathrm{ml}$, respectively. From SPF testing, the SPF values for the $\mathrm{n}$-hexane and chloroform fractions were found to be $11.7 \pm 0.1$ and $21 \pm 0.4$, respectively.

\section{ACKNOWLEDGMENT}

The authors gratefully acknowledge the financial support of the Ministry of Education, Culture, Research, and Technology, Indonesia, for this research. Thanks also go to the Rector of Tanjungpura University, Pontianak City, for providing laboratory facilities.

\section{FUNDING}

This research was fully funded by the Ministry of Education and Culture Research and Technology Indonesia under Contract No 2222/UN22.10/PG/2021.

\section{AUTHORS CONTRIBUTIONS}

All authors were contributed to the idea, designed the study, draft the article, review the data, and edit the article.

\section{CONFLICTS OF INTERESTS}

\section{Authors declare no conflict of interest}

\section{REFERENCES}

1. Skotarczak K, Osmola Mankowska A, Lodyga M, Polanska A, Mazur M, Adamski Z. Photoprotection: facts and controversies. Eur Rev Med Pharmacol Sci. 2015;19(1):98-112. PMID 25635982.

2. Endres L, Breit R, Jordan W, Halbritter W. UV radiation, irradiation, and dosimetry. Dermatol Phototherapy Photodiagnostic Methods. 2009:3-59.

3. Narbutt J. Does the use of protective creams with UV filters inhibit the synthesis of vitamin D for and against? Prz Pediatr. 2009;41:75-81.

4. Jabłonska S, Chorzelski T. Precancerous lesions and carcinomas in situ. [Choroby skóry I choroby Przenowszone drog Płciow PZWL]. Warszawa; 2008. p. 386-417.

5. Dalimartha S. Atlas tumbuhan obat Indonesia [Atlas of Indonesian medicinal plants]. Jakarta: Trubus Agriwidya; 1999. p. 130-1.

6. Joffry SM, Yob NJ, Roffie MS, Affandi MRMM, Suhaili Z, Othman F, Akim ZZA. Melastoma Malabthricum (L.) Smith ethnomedicinal uses, chemical constituents, and pharmacological properties: a review. Evid Based Complement Alternat Med. 2012:1-48.

7. Prasiddha IJ, Rosalina AL, Teti E, Jaya MM. Potential bioactive compounds of corn silk (Zea mays L.) for natural sunscreens: a literature review. Food Agroindustry. 2015;4:40-5.

8. Khairi N. Suryani asad, Djawad K, Alam, G. The determination of antioxidants activity and sunblock Sterculia Populifolia extract-based cream. Pharm Biomed Res Int. 2018;4(1):20-6.

9. Ayodele A, Sodipo O, Sandable U, Shamaki B, Balogun ST, Akinwunmi K. Proximate and elemental analyses, phytochemical screening, and antioxidant activities of aqueous and ethanol extracts of Solanum incanum Linn. fruits. B Pharm Sci. 2021;1(16).

10. Amini MH, Ahmady A, Zhakfar AMA, Sediqi MN, Babak G. Preliminary phytochemical profile, in vitro antioxidant and sun protective activities of alhagi pseudalhagi and elaeagnus angustifolia L. J Pharm Res Int. 2019;31(4):1-13. doi: 10.9734/jpri/2019/v31i430308.

11. Syamsu N, Nursamsiar AM, Aprilia EET, Yulianti R, Burhan A. Screening Bioactivity of Kersen Fruit (Muntingia calabura L.) as a sunscreen candidate. Galenika J Pharm. 2020;7(1):29-38.

12. The health ministry Republic of Indonesia. Pharmacopeia herbal Indonesia. 1st ed. Indonesia; 2008.

13. Wagner $\mathrm{H}$, Bladt S. Plant drug analysis: a thin layer chromatography atlas. Springer; 1996.

14. Giri DP, Rajbhandari M. Phytochemical analysis and constituents of hexane extract of melastoma malabathricum $1 . J$

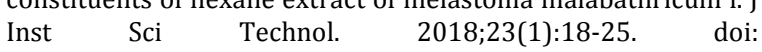
10.3126/jist.v23i1.22150.

15. Brand Williams W, Cuvelier ME, Berset C. Use of a free radical method to evaluate antioxidant activity. LWT Food Sci Technol. 1995;28(1):25-30. doi: 10.1016/S0023-6438(95)80008-5.

16. Kikuzaki H, Hisamoto $M$, Hirose $K$, Akiyama K, Taniguchi H. Antioxidant properties of ferulic acid and its related 
compounds. J Agric Food Chem. 2002;50(7):2161-8. doi: 10.1021/jf011348w, PMID 11902973.

17. Syamsu N, Rumiyati EL. Screening antioxidant activity, antiaging and tyrosinase inhibition from the ethanolic extract and ethyl acetate flesh and skin of langsat fruit (Lansium domesticum Corr) in vitro. Trad Med J. 2017;22(1):63-72.

18. Mansur JS, Breder MNR, Mansur MCA, Azulay RD Determination of sun protecting factors by spectrophotometry. A Bras Dermatol. 1986;61:121-4.

19. Reddy PS, Suresh Kumar A, Jain V. Sunscreens: developments and challenges. Int J App Pharm. 2018;10(6):54-9. doi: 10.22159/ijap.2018v10i6.27379.

20. Nozlena AS, Kamal NNSNM, Yahaya N, Bin Aziz MY, Zain NNM, Yusoff NAM, Lim V. Ethnobotanical, phytochemical and pharmacological aspects of Melastoma sp. Mal J Med Health Sci. 2018;14Suppl 1:153-63.

21. Duke JA. Handbook of biologically active phytochemicals and their activities. CRC Press; 1992.

22. Zayed MZ, Samling B. Phytochemical constituents of the leaves of Leucaena leucocephala from Malaysia. Int J Pharm Pharm Sci. 2016;8(12):1-6

23. Mujeeb F, Bajpai $P$, Pathak N. Phytochemical evaluation, antimicrobial activity, and determination of bioactive components from leaves of Aegle marmelos. BioMed Res Int. 2014;2014:497606. doi: 10.1155/2014/497606, PMID 24900969.

24. Guimaraes AG, Oliveira GF, Melo MS, Cavalcanti SCH, Antoniolli AR, Bonjardim LR, Silva FA, Santos JP, Rocha RF, Moreira JC, Araujo AA, Gelain DP, Quintans-Júnior LJ. Bioassay-guided evaluation of antioxidant and antinociceptive activities of carvacrol. Basic Clin Pharmacol Toxicol. 2010;107(6):949-57. doi: 10.1111/j.1742-7843.2010.00609.x, PMID 20849525.

25. Jacob J, John M. Phytochemical screening and evaluation of leaf parts of Hypoestes phyllostachya rosea for in vitro antioxidant activities. Int J Curr Pharm. 2020;12(5):54-8.

26. Patricio Santos CC, Salvadori MS, Mota VG, Costa LM, de Almeida AAC, de Oliveira GAL, Costa JP, de Sousa DP, de Freitas RM, de Almeida RN. Antinociceptive and antioxidant activities of phytol in in vivo and in vitro models. De Menezes. Neurosci J. 2013:1-9.

27. Blois MS. Antioxidant determinations by the use of a stable free radical. Nature. 1958;181(4617):1199-200. doi: 10.1038/1811199a0.

28. Canda S, Dave R. In vitro models for antioxidant activity evaluation and some medicinal plants possessing antioxidant properties: an overview. Afr J Microbiol Res. 2009;3(13):98196.

29. Molyneux P. The use of stable free radical diphenylpicrylhiydrazyl (DPPH) for estimating antioxidant activity. J Sci Technol. 2004;26(2):212-8.

30. Vaya J, Aviram M. Nutritional antioxidants mechanisms of action, analysis of activities and medical application. Med chem Immunol Endocr Metab. 2001;99-117.

31. Gülçin I. Antioxidant activity of food constituents: an overview. Arch Toxicol. 2012;86(3):345-91. doi: 10.1007/s00204-0110774-2, PMID 22102161.

32. Da Silva VV, Ropke CD, de Almeida RL, Miranda DV, Kera CZ, Rivelli DP, Sawada TC, Barros SB. Chemical stability and SPF determination of Pothomorphe umbellata extract gel and photostability of 4-nerolidylcathecol. Int J Pharm. 2005;303(12):125-31. doi: 10.1016/j.ijpharm.2005.07.006, PMID 16129576.

33. El Sayed KA, Laphookhieo S, Yousaf M, Prestridge JA, Shirode $A B$, Wali VB, Sylvester PW. Semisynthetic and biotransformation studies of $(1 \mathrm{~S}, 2 \mathrm{E}, 4 \mathrm{~S}, 6 \mathrm{R}, 7 \mathrm{E}, 11 \mathrm{E})-2,7,11-$ cembratriene-4,6-diol. J Nat Prod. 2008;71(1):117-22. doi: 10.1021/np0704351. PMID 18177013.

34. Rhodes LE, Shahbakhti H, Azurdia RM, Moison RM, Steenwinkel MJ, Homburg MI, Dean MP, McArdle F, Beijersbergen van Henegouwen GM, Epe B, Vink AA. Effect of eicosapentaenoic acid, an omega-3 polyunsaturated fatty acid, on UVR-related cancer risk in humans. An assessment of early genotoxic markers. Carcinogenesis. 2003;24(5):919-25. doi: 10.1093/carcin/bgg038, PMID 12771037

35. Rhodes LE, Durham BH, Fraser WD, Friedmann PS. Dietary fish oil reduces basal and ultraviolet B-generated PGE2 levels in skin and increases the threshold to provocation of polymorphic light eruption. J Invest Dermatol. 1995;105(4):532-5. doi: 10.1111/1523-1747.ep12323389, PMID 7561154.

36. Rhodes LE, Belgi G, Parslew R, McLoughlin L, Clough GF, Friedmann PS. Ultraviolet-B-induced erythema is mediated by nitric oxide and prostaglandin E2 in combination. J Invest Dermatol. 2001;117(4):880-5. doi: 10.1046/j.0022202x.2001.01514.x, PMID 11676827.

37. Jackson MJ, Jackson MJ, McArdle F, Storey A, Jones SA, McArdle A, Rhodes LE. Effects of micronutrient supplements on u.v.induced skin damage. Proc Nutr Soc. 2002;61(2):187-9. doi: 10.1079/PNS2002158, PMID 12133200. 